Висока школа струковних студија за васпитаче и пословне инфрорматичаре - Сирмијум, Сремска Митровица

DOI 10.5937/kultura1547242K

УДК 316.644-057.874:73/76(497.11)

371.3::73/76(497.11)

оригиналан научни рад

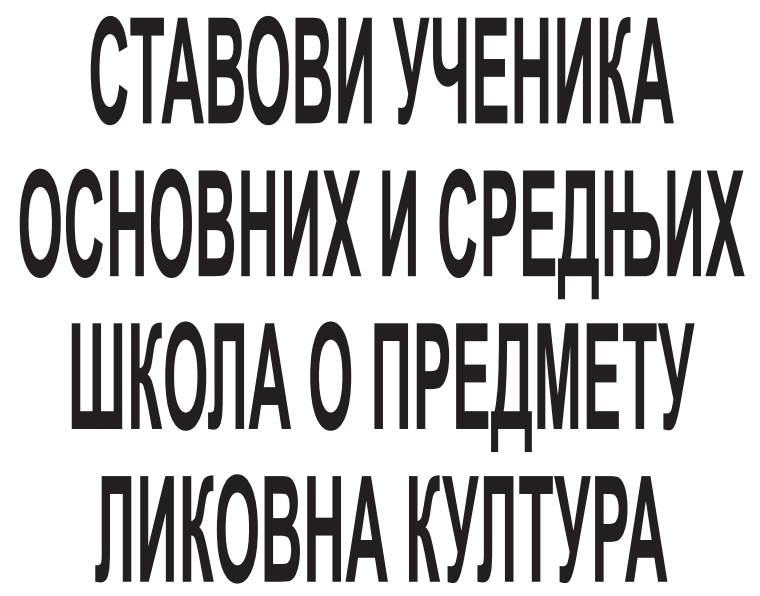

Сажетак: У раду је приказан део резултата истраживања које је имало за цииь да се утврди како ученици процеюују наставни предмет Ликовна култура и како проиенују особине наставника овог предмета. Истраживање је извршено на основу упитника на узорку од 220 ученика основних и средюих школа. Резултати истраживања указују да четвртина испитаних ученика сврстава Ликовну културу у групу омиљених наставних предмета, као и да чешће то чине ученици са нижсим општим успехом, него ученици са вишим. Особине наставника ликовне културе представљају пресудан чинилач када ученици Ликовну културу сврставају у групу омиљених предмета, затим, следе садржаји предмета и наставников приступ раду. Више од половине испитаних ученика сматра да се Ликовна култура мање вреднује у односу на друге предмете и препознаје пресудну улогу наставника ликовне културе у подстицању интересовања младих према ликовним уметностима. У закључним разматраюима указано је да се карактеристике наставног предмета могу посматрати кроз компетениије наставника да планиране садржаје учини приступачним и интересантним за сваког појединачног ученика.

Кључне речи: Ликовна култура, настава ликовне културе, наставник ликовне културе, ставови ученика, компетениије наставника ликовне културе 


\section{$Y_{60} \partial^{l}$}

Савремени аутори који се баве естетским васпитањем, сложни су у вези са ставом о значају и улози уметности и ликовног васпитања за целокупан развој личности (Galbraith, 2003; Day \& Eisner, 2004; Zimmerman, 2010 и др.). Сврха уметности и ликовног васпитања јесте подстицање и развијање креативности тако да она може да се прошири и на друге сфере људских активности ${ }^{2}$. Кроз јединствене форме изражавања и комуникације, које уметност пружа, могу да се усвајају знања, развија апстрактно и дивергентно мишљење, креативност, спонтаност, гради интуиција и имагинација.

Нажалост, о Ликовној култури и уметности уопште, њеном значају, месту и улози у нашем образовно-васпитном систему, још увек постоје бројни неспоразуми, предрасуде и дилеме. Постоје мишљења и ставови у широј јавности али и у просветним круговима, да Ликовна култура, као наставни предмет, није предмет образовно-васпитног карактера, већ да је превасходно рекреативног карактера. Да се на часовима Ликовне културе ученици одмарају после умних напрезања на часовима озбиљних, важних предмета. Постоје и мишљења да уметност не утиче у великој мери на учење и више нивое мишљења. Поред тога, често је се може приметити и став да ликовно стваралаштво, а тиме и Ликовна култура, одговара само талентованим појединцима, који за то показују интересовање, а да ученике који за то немају талента не треба много оптерећивати практичним радом и задацима ликовног изражавања. Речју, чини се да ни у школској пракси, ни у друштвеној, широј јавности, функција Ликовне културе још није довољно прецизно осветљена, нити овај наставни предмет заузима онај положај и третман који му по свему са правом припада ${ }^{3}$.

1 Рад представља део експозеа докторске дисертације Компетениије наставника ликовне културе и могућности њиховог професионалног развоја која је одбрањена на Филозофском факултету Универзитета у Новом Саду, 08. 11. 2013. године, пред комисијом у саставу проф. др Милка Ољача, проф. др Оливера Гајић, проф. др Споменка Будић и проф. др Бојана Шкорц.

2 Zimmerman, E. Lowenfeld Lecture, Creativity Art Education: A Personal Journey in Four Acts, 2010, 03. february 2015. http://www.arteducators.org/ research/lowenfeld lecture_2010_enid zimmerman.pdf

3 Бељкашић, Д. (1985) О развоју и функиији ликовне културе у намем савременом друштву, Ликовна култура, Загреб: Завод за просвјетнопедагошку службу СР Хрватске, стр. 7-23; Кораћ, И. (2008) Положај и функција ликовне културе у односу на друге наставне предмете у основној школи, Методички егземплари, Београд УЛУС, стр. 14-60. 
На положај предмета Ликовна култура у односу на друге наставне предмете говори и податак да је овај наставни премет заступљен са минималним фондом часова, са два часа недељно од II до V разреда, и једним часом недељно у I разреду и од VI до VIII разреда основне школе. Веома мало средњих школа и гимназија има Ликовну културу у наставном плану и програму (иако га има, овај наставни предмет се углавном не реализује у свим разредима и ретко је обавезан). Поред тога, треба имати у виду и да се концепција циљева и задатака, у наставном плану и програму ликовне културе, није мењала више од две деценије.

Резултати нашег раније спроведеног истраживања ${ }^{4}$, чији је циљ био да се утврди мишљење учитеља и наставника ликовне културе о функцији и положају Ликовне културе у односу на друге наставне предмете у основној школи, указују да и учитељи и наставници ликовне културе сматрају да се настава ликовне културе мање вреднује од других наставних предмета у основној школи. Износећи своје незадовољство положајем Ликовне културе у односу на друге наставне предмете, највећи број учитеља и наставника ликовне културе указује на потребу побољшања услова за реализацију наставе овог предмета, пре свега просторну и материјалну.

Слични подаци су добијени и у другом истраживању ауторки Јоксимовић, Вујачић и Лалић-Вучетић ${ }^{5}$ које је имало за циљ да се утврди које аспекте индивидуализације наставници ликовне културе у највећој мери поштују, као и на које начине наставници упознају, уважавају и негују индивидуалне карактеристике ученика. Резултати истраживања, између осталог, указују на то да се настава ликовне културе одвија у посебној учионици која у већини случајева нема одлике правог кабинета за ликовну културу (86,9\% испитаних школа), да наставници у највећем броју немају ни најосновнија средства за рад (репродукције, литературу, боје, глину, керамичке пећи и сл.) и да преко 90\% испитаних наставника није имало прилику да се стручно усавршава. Надаље, наставници ликовне културе веома ретко индивидуализују наставу, партнерски односи, тимски рад и сарадничко понашање нису вредности које се негују код ученика. Одлуке и правила понашања у највећем броју случајева доноси сам наставник. Проблем недисциплине се на часовима најчешће решава опомињањем ученика. Када је у питању процењивање радова ученика, резултати истраживања указују да чак

4 Исто.

5 Јоксимовић, А., Вујачић, М. и Лалић-Вучетић, Н. (2010) Специфичности наставе ликовне културе и потреба за индивидуализованим приступом ученику, Настава и васпитање бр. 2, стр. 191-204. 
70\% испитаних наставника не образлаже ученицима оцене и сл.

Ставови ученика према наставним предметима предмет су бројних истраживања (Бодрошки, 1997; Ђорђевић и Ђорђевић, 1988; Мирков, 2002, 2003; Хавелка, 1997; и др.). Међутим, мало је истраживања која се продубљено и фокусирано баве утврђивањем ставова ученика према предмету Ликовна култура.

За наш рад посебно су значајни резултати истраживања Станковић Јанковић ${ }^{6}$ које је имало за циљ да се утврде ставови ученика према Ликовној култури у односу на пол, узраст и успех (општи успех и успех из Ликовне културе) ${ }^{7}$. Резултати указују да постоји значајна разлика између дечака и девојчица у вредновању Ликовне културе. Наиме, девојчице у већем проценту изражавају позитивне ставове према настави ликовне културе, него дечаци. Девојчице више него дечаци позитивније вреднују наставников рад на часу. Поред тога, резултати указују да постоји међузависан однос вредновања наставе ликовне културе и узраста ученика. „Ученици шестог разреда придају највећи значај Ликовној култури, а потом је приметан тренд опадања са узрастом (до деветог разреда)." ${ }^{8}$ Разлози оваквих налаза ауторка налази у наставном плану и програму, ангажовању наставника (ученицима петог разреда, у Републици Српској где је спроведено истраживање, наставу ликовне културе реализује учитељ, тек од шестог разреда наставу реализује наставник ликовне културе), као и у самој активности ученика. Што се тиче успеха ученика и ставова ученика према Ликовној култури, резултати истраживања указују да су са повећањем успеха из предмета Ликовна култура, како на полугодишту, тако и на крају школске године, ставови ученика према Ликовној култури позитивнији. Међутим, нема статистички значајних корелација када је у питању општи успех ученика и ставови ученика према Ликовној култури. ${ }^{9}$

Поимање сложености наведене проблематике у вези са наставом ликовне културе, између осталог, наметнуло је потребу испитивања мишљења ученика о појединим пита-

6 Станковић Јанковић, Т. (2013) Ликовна култура - неискориштене добробити, Иновације у настави бр. 4, стр. 18-30.

7 Узорком је било обухваћено 320 ученика (од шестог до деветог разреда,) из три основне школе у Бања Луци, Република Српска. Узраст ученика је био од десет до петнаест година, од чега 151 женског пола и 169 мушког пола.

8 Исто, стр. 24.

9 Исто. 
њима у вези са овим наставним предметом. Полазећи од најопштије претпоставке да постоје различити чиниоци који утичу на то да ли ће ученицима предмет Ликовна култура бити у групи омиљених предмета или не, а у намери да проширимо дискусију, посебно смо усмерили пажњу на особине наставника ликовне културе.

\section{Методолошки аспект истраживања}

У раду је приказан део резултата спроведеног истраживања које је имало за циљ да се утврди како ученици основних и средњих школа процењују наставни предмет Ликовну културу и како процењују особине наставника ликовне културе.

У истраживању је коришћен неексперименталан корелациони нацрт уз коришћење методе попречног пресека. Поузданост коришћеног инструмента добијена је израчунавањем Cronbach's alpha коефицијента. Као мере повезаности варијабли израчунаван је коефицијент Пирсонове корелације, Пирсонов $\chi^{2}$ и $\chi^{2}$. За утврђивање значајности разлика између варијабли коришћена је анализа варијансе.

Истраживање је извршено на основу посебно конструисаног упитника. Ученици су имали задатак да издвоје три наставна предмета која воле, која су им омиљена и три наставна предмета која не воле. Затим су процењивали утицај појединих чинилаца на то да им предмет буде у групи предмета које воле, који су им омиљени, односно да им буде у групи предмета које не воле. Поред тога, ученике смо питали да наведу особине које највише и најмање цене код наставника ликовне културе. Посебно нас је занимало како ученици процењују положај Ликовне културе у односу на друге наставне предмете и шта мисле ко има пресудну улогу у подстицању интересовања младих према ликовним уметностима.

У инструменту којим је извршено истраживање издвојили смо контролне варијабле: место где се школа налази, образовна институција, пол ученика, општи успех из предмета Ликовна култура у VII разреду основне школе, општи успех из предмета Ликовна култура у I разреду средње школе општи успех у VII разреду основне школе, општи успех у I разреду средње школе. У првом делу приказа налаза истраживања приказани су резултати у вези са поменутим варијаблама.

Узорак истраживања обухватио је 220 ученика, од тога 80 ученика осмог разреда градских основних школа, 80 ученика осмог разреда сеоских основних школа и 60 ученика прве године средње школе. 


\section{ИСИДОРА КОРАЋ}

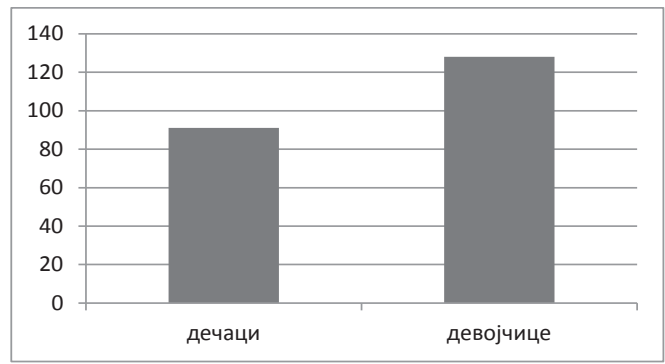

Графикон 1: Расподела ученика по полу

Када посматрамо узорак ученика у односу на успех, видимо да је просечан општи успех ученика у претходном (седмом) разреду врло добар $(4,10)$, док је општи успех из Ликовне културе одличан $(4,76)$. Ниједан испитани ученик није у претходном разреду имао мању оцену из Ликовне културе од оцене добар $(3,00)$.

\begin{tabular}{|l|l|l|l|l|}
\hline Пол & AS & SD & F & p \\
\cline { 1 - 3 } дечаци & 4,635 & 0,588 & & \\
\cline { 1 - 3 } девојчице & 4,875 & 0,416 & 12,429 & 0,001 \\
\hline
\end{tabular}

Табела 1. Разлике у успеху из предмета Ликовна култура у односу на пол ученика

\begin{tabular}{|l|l|l|l|l|}
\hline Школа & AS & SD & F & P \\
\hline основна школа & 4,848 & 0,451 & & \multirow{2}{*}{14,786} \\
\cline { 1 - 3 } средња школа & 4,552 & 0,626 & 0,000 \\
\hline
\end{tabular}

Табела 2. Разлике у успеху из предмета Ликовна култура у односу на школу - основна школа и средња школа

\begin{tabular}{|c|c|c|c|c|}
\hline $\begin{array}{l}\text { Место где се основна } \\
\text { школа налази }\end{array}$ & AS & SD & $\mathrm{F}$ & $p$ \\
\hline село & 4,644 & 0,612 & \multirow[b]{2}{*}{24,729} & \multirow[b]{2}{*}{0,000} \\
\hline град & 4,988 & 0,112 & & \\
\hline
\end{tabular}

Табела 3. Разлике у успеху из предмета Ликовна култура у односу на место где се основна школа налази

Резултати истраживања указују да у основним школама ученици имају бољи општи успех него у средњим школама $(\mathrm{F}(1)=4,121 ; \mathrm{p}=0,044)$ као и бољи успех из предмета Ликовна култура. Девојчице имају значајно бољи успех у школи од дечака $(\mathrm{F}(1)=24,616 ; \mathrm{p}=0,000)$ и имају бољу оцену из предмета Ликовна култура од дечака. Постоје статистички значајне разлике када упоредимо општи успех ученика из основних школа у селу и основних школа граду, ученици из основних школа у селу имају бољи општи успех од ученика у граду $(\mathrm{F}(1)=7,169 ; \mathrm{p}=0,008)$. Ученици са бољим успехом имају и бољу оцену из Ликовне културе $(\mathrm{r}=0,496 ; \mathrm{p}=0,00)$, али генерално гледано сви испитани ученици имају добре оцене из овог наставног предмета. 


\section{Резултати истраживања}

Од ученика смо тражили да наведу три наставна предмета која воле, која су им омиљена и три наставна предмета која не воле, као и да наведу разлоге због којих су им ти предмети омиљени, зашто их воле, односно не воле. Циљ нам је био да видимо да ли ће се Ликовна култура наћи у једној од поменутих група предмета.

Што се тиче, групе омиљених предмета, четвртина испитаних ученика је навела наставни предмет Ликовна култура. Ученици који имају нижи општи успех наводе Ликовну културу у три омиљена предмета више него ученици са вишим успехом $(F(1)=7,82 ; p=0,006)$. Могуће да је један од разлога што се у нашем образовно систему, у наставном процесу, најчешће инсистира на меморисању чињеница, конвергентном мишљењу које није специфично за наставу ликовне културе. Доминира окренутост ка одређеним типовима интелигенције, тестови знања почивају на конвергентном моделу мишљења, услед чега ученици који имају развијен овај тип мишљења показују боље резултате у школском учењу ${ }^{10}$. Са друге стране, ученици склонији дивергентном мишљењу, специфичном за наставу Ликовне културе, који се издвајају по креативним потенцијалима, постижу лошије резултате у школском учењу, не зато што су неинтелигентнији, већ се, у школском контексту, овај модел мишљења не мери у довољној мери ${ }^{11}$. Наведено указује на потребу додатних истраживања како би се овај феномен разјаснио.

Надаље, да ли ће предмет Ликовна култура бити у групи омиљених предмета или не, не зависи од оцене ученика из овог наставног предмета $(\mathrm{F}(1)=2,10 ; \mathrm{p}=0,148)$. Међутим, за извођење закључака у вези са добијеним податком неопходна провера на узорку већег броја испитаника који имају различит распон оцена на скали од један до пет.

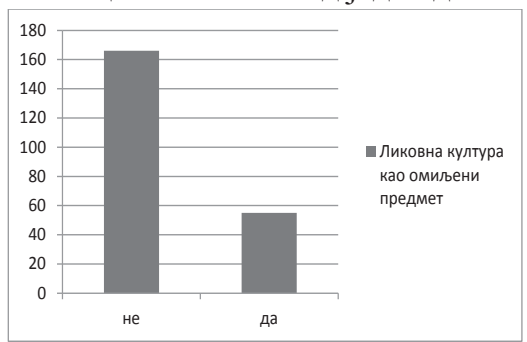

Графикон 2: Број ученика који Ликовну културу сматра омиљеним предметом

10 Максић, С. (2006) Подстицање креативности у школи, Београд: Институт за педагошка истраживања.

11 Шкорц, Б. (2012) Креативност у интеракичији, Београд: Мост арт. 
Слични резултати добијени су у истраживању које је спровела Мирков $(2003)^{12}$ у којем су испитивани узроци проблема у учењу на узорку ученика осмог разреда основне школе. Узорак је чинило 335 ученика основних школа. Позитиван став према Ликовној култури изражава скоро четвртина узорка ученика (од тога $34,6 \%$ са одличним општим успехом, $24,4 \%$ са врло добрим, а 21,8\% са недовољним). Ученици који су чинили узорак већином имају одличну оцену из тог предмета $(73,1 \%)$.

Затим, подједнако и девојчице и дечаци наводе Ликовну културу у групу три омиљена наставна предмета $\left(\chi^{2}(1)=0,664\right.$; $\mathrm{p}=0,415)$. Такође, подједнако често и у основним и у средњим школама наводе Ликовну културу у групи омиљених предмета $\left(\chi^{2}(1)=3,143 ; \mathrm{p}=0,076\right)$. Подједнако често наводе Ликовну културу у групи омиљених предмета и ученици из сеоских и ученици из градских основних школа $\left(\chi^{2}(1)=\right.$ $0,190 ; p=0,168)$.

Надаље, поменули би и резултате истраживања који указују да поред Ликовне културе, 49,3\% ученика наводи предмете из природне групе предмета као омиљене, док 66,5\% ученика наводи предмете из друштвене групе.

Занимљив је податак да чак 44\% ученика средње школе не наводи стручне предмете у омиљене. Када смо ученике средњих школа питали да наведу предмете које не воле, чак $41 \%$ испитаних ученика је навело неки предмет из групе стручних предмета. Податак отвара питања професионалне оријентације ученика, затим, садржаја и организације стручних предмета у средњим школама, које могу бити теме за нека од наредних истраживања.

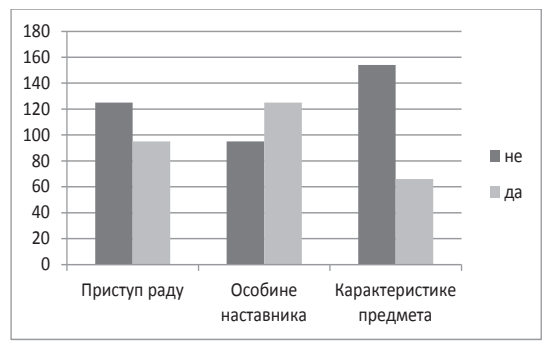

Графикон 3: Разлози за избор предмета у групу омиљених

Када анализирамо разлоге због којих су им предмети омиљени, можемо видети да 56,6\% ученика наводи да су то особине наставника, и то подједнако наводе и девојчице и дечаци

12 Мирков, С. (2003) Узроци проблема у учењу код ученика основне школе, Зборник Института за педагошка истраживања, Београд: Институт за педагошка истраживања, стр.151-165. 
$\left(\chi^{2}(1)=2,613 ; p=0,106\right)$. Затим, 43,2\% ученика, без обзира на пол $\left(\chi^{2}(1)=2,454 ; p=0,117\right)$, наводи да је разлог наставников приступ у реализацији наставе (начин рада, методе, организација часа и сл.), а 29,9\% њих наводи карактеристике самог предмета, такође без обзира на пол $\left(\chi^{2}(1)=1,540 ; p=0,215\right)$. Судећи по овим резултатима, можемо закључити да већи број чинилаца утиче на то који ће наставни предмет бити омиљен за ученике, али су, без обзира на пол, за највећи број ученика пресудне особине наставника.

Приступ у раду наставника важнији је основцима него средњошколцима $\left(\chi^{2}(1)=4,459 ; \mathrm{p}=0,35\right)$, као и особине наставника $\left(\chi^{2}(1)=13,247 ; p=0,000\right)$. У односу на то да ли се основна школа налази у селу или граду, нема статистички значајних разлика. Ученицима основних школа, без обзира где се оне налазе, су подједнако битне и особине наставника, приступ раду и карактеристике предмета када процењују да ли су им предмети омиљени или не $\left(\chi^{2}(2)=2,142 ; \mathrm{p}=0,153\right)$.

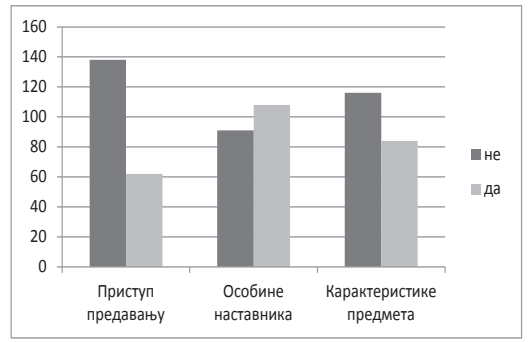

Графикон 4: Разлози за избор предмета у групу предмета које ученици не воле

Слични резултати добијени су и када су ученици наводили разлоге због који наставне предмете сврставају у групу предмета које не воле. Као што се из Графикона 5 може видети, ученици у највећем броју $(48,9 \%)$ наводе да су особине наставника разлог због које не воле одређени наставни предмет. Нешто мање ученика (38\%) наводи да је разлог сам предмет, његове карактеристике, а најмање ученика $28 \%$ наводи приступ наставника у раду (начин рада, методе, организација часа и сл.).

Ако упоредимо мишљење ученика основних и средњих школа, постоје статистички значајне разлике. Наиме, када наводе разлоге зашто им је предмет у групи предмета које не воле, особине наставника су пресудније ученицима основних школа $\left(\chi^{2}(1)=5,071 ; p=0,024\right)$.

Дакле, и када бирају предмет који не воле, ученицима су пресудне особине наставника и оне су важније ученицима основних него ученицима средњих школа. Разлике постоје ако упоредимо податке о томе које разлоге ученици наводе 
зашто су им предмети омиљени или не. Наиме, карактеристике предмета мање утичу на то да ученици предмет наведу у групу омиљених, него у групу предмета које не воле. Наведене разлике су занимљиве када анализирамо како ученици бирају у односу на то шта им је значајно, а шта није.

Посебно смо анализирали одговоре ученика који су навели Ликовну културу у групу омиљених, односно групу предмета које не воле.

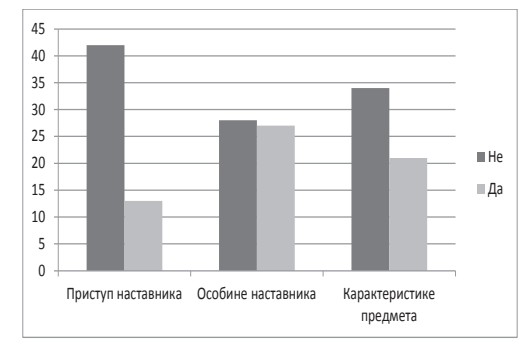

Графикон 5: Разлози због којих ученици Ликовну културу наводе међу три омиљена предмета

Разлоге које наводе зашто им је Ликовна култура у групи омиљених су у највећем броју особине наставника. Готово половина испитаних ученика (49\%) наводи овај разлог, следе, карактеристике предмета $(38,2 \%)$, па тек онда наставников приступ раду (начин рада, методе, организација часа и сл.) $(23,6 \%)$.

Приступ наставника ликовне културе је значајно важнији основцима него средњошколцима $\left(\chi^{2}(1)=4,459 ; \mathrm{p}=0,035\right)$, као и његове особине личности $\left(\chi^{2}(1)=13,247 ; \mathrm{p}=0,000\right)$. Овај резултат упућује на закључак да старији ученици више доводе у везу своја интересовања са самим садржајем предмета Ликовна култура.

Ако упоредимо ове одговоре ученика и одговоре које дају када наводе разлоге због којих су им други предмети омиљени, видимо да постоје разлике. Наиме, када наводе разлоге због којих су им други предмети омиљени, највише ученика наводи да су то особине наставника, затим, наставников приступ раду (начин рада, методе, организација часа и сл.), а на трећем месту наводе карактеристике самог предмета. Када су у питању разлози због којих им је Ликовна култура омиљени предмет, особине наставника су и овде пресудне, али су садржаји предмета на другом месту, испред наставниковог приступа раду. Мислимо да је разлог томе што ученици доводе у везу своја интересовања са способностима које поседују, јер се садржаји доминантно везују за различите специјалне способности. 
Овај резултат истраживања можемо у великој мери довести у везу са резултатима истраживања које је спровела Бодрошки (1997) ${ }^{13}$, а који указују да Ликовна култура спада у групу предмета код којих самопроцена сопствених способности од стране ученика има великог утицаја на њихово интересовање за предмет ${ }^{14}$.

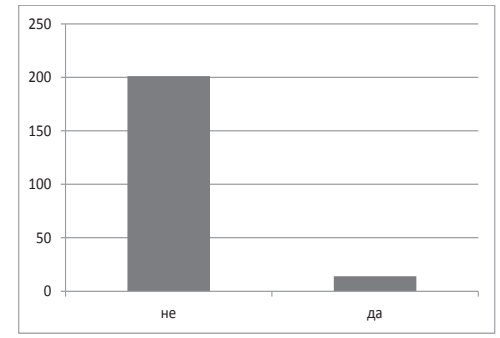

Графикон 6: Број ученика који Ликовну културу сврстава у групу предмета које не воли

Охрабрује податак да је само 6,3\% испитаних ученика основних школа навело Ликовну културу међу наставне предмете које не воли (док је рецимо 25\% испитаних ученика навело Српски језик и књижевност, 31\% испитаних ученика Математику, 56\% испитаних ученика предмете из групе природних наука, 54\% предмете из групе друштвених наука). Ниједан ученик средње школе није навео Ликовну културу у групу предмета које не воли.

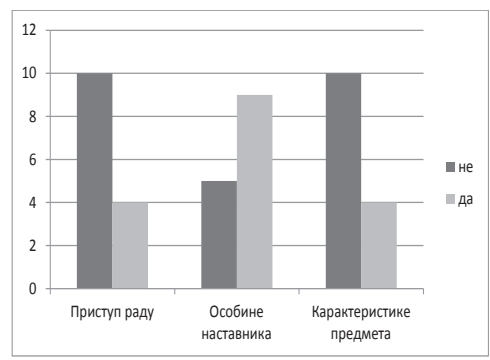

Графикон 7: Разлози због којих ученици не воле Ликовну културу

13 Бодрошки, Б. (1997) Чиниоци интересовања за наставне предмете, Истраживања у педагогији и андрагогији, Београд: Институт за педагогију и андрагогију Филозофског факултета, стр. 69-73.

14 Предмет истраживања био је структура и корелат интересовања за наставне предмете. Утицај појединих чинилаца на интересовање испитиван је на узорку ученика осмог разреда београдских основних школа, на основу формулисаних ставки које описују могуће разлоге или утицаје, а односе се на занимљив садржај предмета, позитиван однос ученика према наставнику (волим и иеним наставника), добре и занимљиве уџбенике, процену сопствене способности за учење одређеног наставног предмета; а ученицима је остављена и могућност да сами додају неки чинилац. 
Када смо питали ученике да наведу разлоге због којих не воле Ликовну културу, највећи број ученика наводи особине наставника ликовне културе $(64,3 \%)$, а једнак број ученика наводи да разлози леже у приступу наставника $(28,6 \%)$ и карактеристикама наставног предмета $(28,6 \%)$.

Дакле, особине наставника, његова личност чини пресудан фактор када се ученици опредељују за то да ли им је предмет омиљен или не. И овде видимо да су основцима особине наставника пресудније да Ликовну културу наведу у групу предмета које не воле, него средњошколцима $\left(\chi^{2}(1)=5,071\right.$; $\mathrm{p}=0,024)$.

Надаље, питали смо ученике и да наведу особине које највише цене код наставника ликовне културе.

\begin{tabular}{|l|l}
\hline $\begin{array}{l}\text { Карактеристике које ученици највише цене код наставника } \\
\text { ликовне културе }\end{array}$ & $\begin{array}{l}\% \\
\text { ученика }\end{array}$ \\
\hline разумевање за ученике и блискост са њима & 57.7 \\
\hline правичност у оцењивању & 48.7 \\
\hline личне особине & 47.5 \\
\hline добро организује час & 41.4 \\
\hline уме да мотивише ученике & 32.2 \\
\hline добро објашњава & 31.3 \\
\hline добар стручњак & 30.6 \\
\hline јасно поставља захтеве & 26.3 \\
\hline
\end{tabular}

Табела 4. Карактеристике које ученици највише цене код наставника ликовне културе

Резултати приказани у Табели 4 указују да више од половине испитаних ученика код наставника ликовне културе највише цени особину: разумевање за ученике и блискост са њима, нешто мањи број: правичност у оцењивању и његове личне особине, затим следе: организација часа, мотивација ученика, вештина доброг објашњавања, стручност и јасноћа у постављању захтева. На овом месту, задржали би се код личних особина које ученици наводе. У одговорима испитаника наведене су: ведрина и духовитост, креативност, доброта, марљивост, искреност, доследност, стрпљење, љубав према послу, харизма, поштење, пристојност, љубазност, сталоженост, комуникацијске вештине, тачност, уредност, одговорност. У одговорима се јављају и спољашње особине наставника као што су лепота, уредан изглед, лепо облачење.

Резултати приказани у Табели 5 указују да се чак 74,7\% испитаних ученика изјашњава да им код наставника ликовне културе највише смета особина: лош однос са ученицима, затим следе: личне особине наставника, лоша организација часа, високи критеријуми у оцењивању, лоша предавања - неразумљивост и незанимљивост предавања. На овом 
месту, задржали би се код личних особина наставника које ученици наводе да им сметају. У одговорима испитаника наведене су следеће особине: саркастичност, нервоза, непристојност, површност, импулсивност. Када описују лошу организацију часа ученици се жале на претешке контролне задатке, досадне теме, превише теорије, стално смо у учионици, наставник често касни на час, бави се само талентованим ученицима.

\begin{tabular}{|l|l|}
\hline $\begin{array}{l}\text { Карактеристике које сметају ученицима код наставника } \\
\text { ликовне културе }\end{array}$ & $\begin{array}{l}\% \\
\text { ученика }\end{array}$ \\
\hline лош однос према ученицима & 74.7 \\
\hline личне особине & 57.5 \\
\hline лоша организација часа & 45.5 \\
\hline високи критеријуми у оцењивању & 34.4 \\
\hline лоша предавања, неразумљивост & 32.2 \\
\hline незанимљивост предавања & 31.3 \\
\hline
\end{tabular}

Табела 5. Карактеристике које сметају ученицима код наставника ликовне културе

Занимало нас је и како ученици процењују положај Ликовне културе у односу на друге наставне предмете. Резултати истраживања указују да у процени положаја ликовне културе у односу на друге наставне предмете у основној школи испитани ученици немају јединствен став. Највећи број ученика (60\%) сматра да се Ликовна култура мање вреднује у односу на друге наставне предмете, $13 \%$ ученика сматра да је у истом рангу са другим наставним предметима, $25 \%$ ученика не може да процени и само 2\% сматра да се више вреднује од других наставних предмета.

Надаље, највећи број испитаних ученика (53\%) препознаје пресудну улогу наставника ликовне културе у подстицању интересовања младих према ликовним уметностима. Након наставника ликовне културе, као кључни актер у подстицању интересовања младих према ликовним уметностима, ученици препознају школу (27\%), затим, медије (13\%), родитеље $(5 \%)$, док вршњаке наводи само $2 \%$ испитаних ученика.

\section{Закључак}

Истраживање ставова ученика о настави јесте један од изузетно важних аспеката вредновања образовно-васпитног рада наставника. Спроведено истраживање је недвосмислено указало на важност улоге наставника, његових компетенција за успешну реализацију наставе Ликовне културе.

Резултати истраживања указују да већи број чинилаца утиче на то који ће наставни предмет ученицима бити омиљен, а 
који неће. Када наводе разлоге због којих су им други предмети омиљени, највише ученика наводи да су то особине наставника, затим наставников приступ раду (начин рада, методе, организација часа и сл.), а на трећем месту наводе карактеристике самог предмета. Када су у питању разлози због којих им је Ликовна култура омиљени предмет, особине наставника су и овде пресудне, али су садржаји предмета на другом месту, испред наставниковог приступа раду. Мислимо да је разлог томе што ученици доводе у везу своја интересовања са способностима које поседују, јер се садржаји доминантно везују за различите специјалне способности. Дакле, Ликовна култура спада у групу наставних предмета код којих самопроцена сопствених способности ученика има утицаја на њихово интересовање за предмет ${ }^{15}$. Овај податак може да представља изазов за наставника, јер не треба изгубити из вида да наставник, својим начином рада, може утицати на самопроцену сопствених способности ученика. Наставник треба да створи прилику да сваки ученик буде успешан у оквиру својих способности, да би увидео везу између успеха и сопствене акције (улагања, труда), што се може постићи адекватном повратном информацијом о учениковом постигнућу. Вредновање постигнућа ученика, оцењивање, треба схватити као интеракцијски, вишесмеран процес који има различите функције у односу на ученика: информативну, евалуативну, инструктивну, мотивациону, развојну и социјалну функцију.

Надаље, резултати истраживања о особинама наставника ликовне културе отварају питања компетенција наставника и мотивисаности наставника за рад. Дакле, карактеристике наставног предмета могу се посматрати и кроз компетенције наставника да планиране садржаје учини приступачним и интересантним за сваког појединачног ученика.

Поред тога, треба имати у виду да понашање и ангажовање ученика у школи у великој мери зависи и од тога како виде и доживљавају поједине сегменте школске ситуације. Са тим у вези, сматрамо да резултати истраживања у вези са проценом ученика о положају Ликовне културе у односу на друге наставне предмете, указују да предмет Ликовна култура захтева комплексна научна истраживања са циљем: да се створи чврста и широка научна подлога и обезбеди друштвена подршка за даљи рад на њеном унапређивању. Кључни актери у подстицању интересовања младих према

15 Видети и истраживање у: Бодрошки, Б. (1997) Чиниоци интересовања за наставне предмете, Истраживања у педагогији и андрагогији, Београд: Институт за педагогију и андрагогију Филозофског факултета, стр. 69-73. 
ликовним уметностима и промовисању вишеструке функције коју Ликовна култура има у целокупном развоју личности, а самим тим и побољшању положаја Ликовне културе у односу на друге наставне предмете, су: школа, наставник ликовне културе, али и креатори образовне политике.

\section{ЛИТЕРАТУРА:}

Бељкашић, Д. (1985) О развоју и функиији ликовне културе у нашем савременом друштву, Ликовна култура, Загреб: Завод за просвјетно-педагошку службу СР Хрватске, стр. 7-23.

Бодрошки, Б. (1997) Чиниоци интересовања за наставне предмете, Истражсиваға у педагогији и андрагогији, Београд: Институт за педагогију и андрагогију Филозофског факултета, стр. 69-73.

Galbraith, L. (2003) The Promise and Importance of Research on Art(s) Teacher Education, National Art Education Association.

Day, M. and Eisner, E. (2004) Handbook of Research and Policy in Art Education, National Art Education Association.

Ђорђевић, Б. и Ђорђевић Ј. (1988) Ученици о својствима наставника, Београд: Просвета.

Zimmerman, E. (2010) Lowenfeld Lecture, Creativity Art Education: A Personal Journey in Four Acts, 03. february 2015. http://www.arteducators.org/research/lowenfeld lecture_2010_enid zimmerman.pdf

Јоксимовић, А., Вујачић, М. и Лалић-Вучетић, Н. (2010) Специфичности наставе ликовне културе и потреба за индивидуализованим приступом ученику, Настава и васпитање, бр. 2, стр. 191-204.

Кораћ, И. (2008) Положај и функција ликовне културе у односу на друге наставне предмете у основној школи, Методички егземплаpu, Београд: УЛУС, стр. 14-60.

Максић, С. (2006) Подстииање креативности у школи. Београд: Институт за педагошка истраживања.

Мирков, С. (2002) Неки чиниоци формирања ставова према наставним предметима, Настава и васпитање бр. 5, стр. 383-399.

Мирков, С. (2003) Узроци проблема у учењу код ученика основне школе, Зборник Института за педагошка истраживања, Београд: Институт за педагошка истраживања, стр.151-165.

Станковић Јанковић, Т. (2013) Ликовна култура - неискориштене добробити, Иновације у настави, бр. 4, стр. 18-30.

Хавелка, Н. (1997) Ученички доживљај школе: како ученици процењују наставне предмете, Психолошка истраживаға бр. 9, стр. 177-217.

Шкорц, Б. (2012) Креативност у интеракиији. Београд: Мост арт. 


\title{
ИСИДОРА КОРАЋ
}

Isidora Korać

College for Applied Studies for Teachers and Business IT Experts Sirmium, Sremska Mitrovica

\section{ATTITUDES OF PRIMARY AND SECONDARY SCHOOL STUDENTS TO ART CULTURE}

\begin{abstract}
The paper presents results of a research aimed at determining how students evaluate Art as a school subject and how they assess Arts teachers' traits. The research was based on a questionnaire given to a sample of 220 primary and secondary school students. The research results indicate that a quarter of students classify Art classes among favorite subjects, those often being the students with lower general success rate than students with the higher one. There are no statistically significant differences when comparing the results of research in relation to variables: students' gender, the mark in Art, age and educational institutions. Art teachers' traits are a critical factor for students who put Art classes in the group their favourite subjects, followed by the contents of the subject and the teacher's approach to work. Results of the research on the Art teachers' traits raise questions of teachers' competences and motivation for work. More than a half of the respondents considered that Art as a subject is less valued when compared with other subjects, and they recognized the role of art teachers as a crucial one in encouraging the youth interest in visual arts. Concluding remarks indicate that the characteristics of the subject can be viewed through the competences of teachers to make the planned contents more accessible and interesting to each individual student. It is believed that the results of the study indicate that the subject of Art requires complex scientific research with the aim to create a solid and broad scientific basis and provide the social support for its further improvement. Key actors in encouraging the youth interests in visual arts and the promotion of multiple functions that Art has in the overall development of personality, and thereby in improving the status of arts in relation to other subjects, are not only school and Art teachers, but education policy-makers as well.
\end{abstract}

Key words: art, art classes, art teacher, students'attitudes 